ACTA UNIVERSITATIS LODZIENSIS

FOLIA LITTERARIA POLONICA 1(31) 2016

http://dx.doi.org/10.18778/1505-9057.31.05

Maria Załęska*

\title{
Retoryczne aspekty popularyzacji naukowej
}

\author{
Nie wystarczy mówić do rzeczy. \\ Trzeba mówić do ludzi. \\ S.J. Lec
}

\section{Wstęp}

Wymowną ilustracją zabiegów retorycznych, stosowanych przez badaczy w popularyzacji wiedzy naukowej w mediach na imprezach popularyzatorskich, może być rozmowa o zwycięskiej prezentacji na konkursie FameLab:

- Właśnie wygrałaś polski FameLab. Co to za konkurs?

- Zmusza młodych naukowców do opowiedzenia o jakiejś koncepcji naukowej w zrozumiały i atrakcyjny sposób do „nienaukowej publiczności” i trwa trzy minuty.

Można w trakcie używać niewielkich rekwizytów.

- Ty wyszłaś na scenę w szlafroku i...?

- Spytałam panów, czy spaliby spokojnie, gdybym im powiedziała, że podczas snu kurczą im się jądra.

- I co? Pomruk grozy na sali?

- Raczej chichot. I zaciekawienie. Opowiadałam przede wszystkim o chomikach, którym podawano melatoninę $[\ldots]^{1}$.

Problem naukowy - hipoteza dotycząca relacji przyczynowo-skutkowych między wyróżnionymi czynnikami (przyczyna: działanie melatoniny; skutek: zachowanie chomików) - został przedstawiony w sposób „sexy”, działający na wyobraźnię szerokiej publiczności, zapadający w pamięć dzięki anegdocie.

* Dr hab., e-mail: maria.m.zaleska@gmail.com; Uniwersytet Warszawski, Wydział Neofilologii, Katedra Italianistyki; 00-332 Warszawa, ul. Oboźna 8.

${ }^{1}$ Zoolożka, z J. Bagniewską rozm. M. Borowska, „Gazeta Wyborcza” 2014, 28.06, dodatek „Wysokie Obcasy”, nr 25 (784), s. 8. 
Przytoczony fragment rozmowy posłuży tu za punkt odniesienia do porównania strategii retorycznych w komunikacji naukowej i popularnonaukowej.

Skoro popularyzacja stanowi pożądaną aktywność komunikacyjną, wpisując się w strategię kształtowania „społeczeństwa wiedzy”, warto się zastanowić, czy - mówiąc inaczej (albo naukowo, albo popularyzatorsko) - mimo wszystko mówimy to samo? A jeśli nie mówimy tego samego - to... co mówimy? Skoro „,[...] retoryka zdaje się być umiejętnością odkrywania w każdym [...] przypadku tego, co przekonywające [...]" (Arystoteles, Retoryka 1355b), jakie środki retoryczne odkrywają na swój użytek naukowcy w działalności wiedzotwórczej, a jakie dziennikarze (i często naukowcy) w działalności „wiedzoodtwórczej”?

Wprawdzie istnieje wiele form pośrednich między orientacyjnymi dwoma biegunami - specjalistyczną komunikacją naukową i popularyzacją - ale ze względu na ograniczenia objętościowe artykułu skupimy się tylko na tych dwóch sposobach wypowiedzi, dla uwydatnienia różnic między nimi. Dla systematycznego porównania sposobów konstrukcji przekazu naukowego i popularnonaukowego poniżej zostaną omówione: pierwszy zaświadczony model relacji między komunikowaniem specjalistycznym i niespecjalistycznym; współczesne ujęcia różnic między komunikacją specjalistyczną i niespecjalistyczną oraz porównanie komunikacji naukowej i popularyzatorskiej w ramach trzech kategorii retorycznych: dispositio, inventio i elocutio.

\section{Od komunikacji ezoterycznej do egzoterycznej}

Już w antycznych rozważaniach nad sposobami komunikacji zauważono, że audytorium determinuje sposób komunikacji. W kontekście przekazywania wiedzy (szczególnie dydaktycznym) starożytni dokonywali rozróżnienia - na podstawie tego, jak Arystoteles zwracał się do mniej lub bardziej zaawansowanych słuchaczy - między sposobem mówienia zwanym „wewnętrznym” i ,zewnętrznym".

Sposób mówienia określany jako „wewnętrzny” - czyli, w ówczesnej nomenklaturze, ezoteryczny (gr. esoterikós) - dotyczył nauczania, jakiego Arystoteles udzielał uczniom już zaawansowanym w wiedzy, zdolnym rozumieć złożone kwestie omawiane na wykładach filozofa. Ten sposób przekazywania wiedzy zwano też akroamatycznym (gr. akroàmai 'słucham'): wąskie grono wybranych uczniów przysłuchiwało się wywodowi mistrza. W ogólności, określenie to dotyczyło nauczania udzielanego elitarnym grupom wybranych, już zaawansowanych w danej dziedzinie wiedzy (stąd zresztą wzięło się współczesne znaczenie ezoteryczności jako wiedzy dla niewielu wtajemniczonych). „Wewnętrzny” sposób mówienia możliwy był do zastosowania jedynie w sytuacji zmniejszającej 
się asymetrii między wiedzą nadawcy a wiedzą odbiorców, już zaawansowanych w danej dyscyplinie. Poważne aspiracje słuchaczy do uzyskania wiedzy specjalistycznej sprawiały bowiem, że dzięki nauce dążyli oni do stania się równymi mistrzowi ${ }^{2}$.

Ten „ezoteryczny” sposób mówienia jest charakterystyczny dla artykułów naukowych, w których specjalista mówi do specjalistów. Specjaliści podzielają ogromny zasób wiedzy wspólnej - aksjomaty, presupozycje, domyślne dla specjalistów reguły argumentacji typowe dla danej dyscypliny ${ }^{3}$, terminologię - które czynią teksty nierzadko hermetycznymi dla niespecjalistów.

Sposób mówienia określany jako ,zewnętrzny” - czyli, w ówczesnej nomenklaturze, egzoteryczny (gr. exoterikós) - dotyczył natomiast przekazywania wiedzy niespecjalistom, w formie popularnej, bez rygorów naukowych. Początkowo zwrot ten stosowano do ksiąg Arystotelesa, które przedstawiały wiedzę w sposób prosty (w odróżnieniu od ksiąg ezoterycznych, wymagających zaawansowanej wiedzy i napisanych językiem specjalistycznym).

Ten ,zewnętrzny” sposób mówienia może zatem być uznany za model, na którym wzorują się teksty popularne i popularnonaukowe, skierowane do czytelników-niespecjalistów. Ich zaledwie elementarne pojęcie o temacie sprawia, że autor tekstu nie może zakładać wiedzy wspólnej w zakresie poruszanej kwestii. Co najwyżej, może się odwoływać do zasobu doświadczeń codziennych, aby przybliżyć omawiany problem, używając języka niespecjalistycznego i eliminując z prezentacji reguły rozumowania kontrintuicyjnego, wypracowanego w ramach danej dyscypliny.

\section{Od komunikacji naukowej do popularyzacji}

Długo, trudno i żmudnie. Wiedza specjalistyczna jest bardzo kosztowna: wymaga dużego nakładu czasu, uwagi, wysiłku intelektualnego włożonego w zrozumienie skomplikowanych teorii i nabycie kompetencji lingwistycznych w zakresie terminologii, a także - na dalszym etapie - w działalność wiedzotwórczą $^{4}$. Relatywnie niewielu jest skłonnych aż tyle zainwestować, zwłaszcza że im bardziej zaawansowany poziom, tym rozmówców coraz mniej.

\footnotetext{
${ }^{2}$ Por. współczesne pojęcie peers ('równych sobie'): członków wspólnoty naukowej, którzy właśnie jako równi sobie - nawzajem oceniają swoje prace np. w procesie peer review ('recenzji koleżeńskiej').

${ }^{3}$ Zwane field-dependent rules (zob. S. Toulmin, R.D. Rieke, A. Janik, An Introduction to Reasoning, Macmillan Publishing Company, New York-London 1984, p. 17).

${ }^{4}$ Zob. M. Gotti, Specialized discourse: linguistic features and changing conventions, Peter Lang, Bern 2003.
} 
Krótko, łatwo i przyjemnie. Populus 'lud' - czyli szeroka publiczność - preferuje raczej popularyzację: dostęp do wiedzy uzyskany tańszym kosztem, dzięki swoistym ,zamiennikom”: użyciu języka codziennego zamiast specjalistycznego, konkretu zamiast abstrakcji, podobieństwa do codziennych doświadczeń zamiast rozumowania kontrintuicyjnego. Tego typu działalnością „wiedzoodtwórczą” informowaniem o nowych koncepcjach naukowych, referowaniem oryginalnych sposobów myślenia - zajmują się naukowcy, dziennikarze, piszący dla mediów ${ }^{5}$ lub tłumaczący teksty dotyczące nauki ${ }^{6}$, lecz także amatorzy, szczególnie zainteresowani jakimś wycinkiem wiedzy. Im prostszy i atrakcyjniejszy przekaz, tym więcej odbiorców?

Współcześni badacze popularyzacji naukowej ${ }^{8}$ traktują ją jako formę adaptacji oryginału do zmienionych warunków użytkowania: zmiana sytuacji komunikacyjnej powoduje zmianę sposobu mówienia. Oryginalne treści z tekstu naukowego, skonstruowane według konwencji komunikowania między specjalistami, należy przekształcić tak, by trafiały do odbiorcy-niespecjalisty 9 .

Używając terminów współczesnych, między tekstami naukowymi, „wiedzotwórczymi”, a popularnonaukowymi, „wiedzoodtwórczymi”, istnieje zatem relacja intertekstualności. Z punktu widzenia typologii tekstów Egona Werlicha ${ }^{10}$ teksty „wiedzotwórcze” zaliczane są do tekstów argumentacyjnych. Ich podstawowym celem retorycznym jest docere 'nauczanie', czyli - w komunikacji naukowej informowanie o rzeczywistości i/lub jej nowych modelach. Zgodnie z tradycyjnym (i wielokrotnie kontestowanym ${ }^{11}$ ) założeniem, „fakty mówią same za

${ }^{5}$ Zob. G. Myers, Discourse studies of scientific popularization: questioning the boundaries, "Discourse Studies" 2003, 5 (2), pp. 265-279.

${ }^{6}$ Zob. T. Konik, Przypadki retorycznie istotnych zmian redakcyjnych $w$ thumaczeniach publicystyki prasowej o tematyce gospodarczej, [w:] Retoryka w komunikacji specjalistycznej, red. M. Załęska, Polskie Towarzystwo Retoryczne, Warszawa 2015.

${ }^{7}$ Jednak bywają przypadki kontestacji ułatwień przez samych odbiorców, co ilustruje przypadek ożywionych reakcji czytelników na pogłoski o opublikowaniu słynnej książki Umberto Eco Imię róży w wersji uproszczonej; zob. M. Załęska, La semplicità e la semplificazione: fra l'ideologia e la retorica, "Circula: Révue d'idéologies linguistiques" 2015, No 2, pp. 192-211, http:// circula.recherche.usherbrooke.ca/2015-numero-2-fr/ [dostęp: 3.11.2015].

${ }^{8}$ Np. T. Piekot, Mechanizmy popularyzowania wiedzy naukowej, [w:] O trudnym łatwo: materiały sesji poświęconej popularyzacji nauki, red. J. Miodek, M. Zaśko-Zielińska, Wydawnictwo UWr, Wrocław 2002, s. 4; A. Starzec, Przemiany w popularyzacji prasowej, [w:] O trudnym..., s. 25; P. Donghi, Sui generis. Temi e riflessioni sulla comunicazione della scienza, Gius, Laterza \& Figli, Roma-Bari 2006, p. 56.

${ }^{9}$ M. Załęska, Retoryka a wiedza: komunikacja niespecjalistyczna i specjalistyczna, [w:] Retoryka w komunikacji..., s. 53-83.

${ }^{10}$ E. Werlich, Typologie der Texte. Entwurf eines textlinguistischen Modells zur Grundlegung einer Textgrammatik, Quelle \& Meyer, Heidelberg 1975.

${ }^{11}$ Zob. np. S. Shapin, Never Pure. Historical Studies of Science as if It Was Produced by People with Bodies, Situated in Time, Space, Culture, and Society, and Struggling for Credibility and Authority, The Johns Hopkins University Press, Baltimore 2010. 
siebie”: zatem to właśnie ich wymienienie w tekście miałoby być wystarczające do przekonywania (movere). Cel estetyczny tekstu - delectare - w tradycyjnym ujęciu uchodzi za najmniej istotną w komunikacji naukowej (choć czasem jest z powodzeniem realizowany, np. przez Galileusza ${ }^{12}$ ).

Z punktu widzenia typologii Werlicha teksty „wiedzoodtwórcze” zaliczane są do tzw. tekstów referujących (expository texts), znajdujących się w relacji intertekstualności w stosunku do oryginału. Konwencje komunikowania wiedzy dla niespecjalistów - czyli gatunki mowy stosowane w działalności „wiedzoodtwórczej" - wpisują się w umowne, orientacyjne continuum, w ramach którego można umieścić poszczególne gatunki mowy: teksty popularne (np. krótkie notki o ciekawostkach naukowych), popularyzatorskie (dłuższe teksty, zawierające okazjonalne odniesienia do badań naukowych; także np. blogi eksperckie czy wspomniane wyżej występy na FameLab) oraz popularnonaukowe (dłuższe teksty, systematycznie referujące badania prowadzone przez specjalistów na określony temat).

Przedstawienie niespecjalistom wiedzy specjalistycznej - w gazetach, czasopismach, na festiwalach nauki czy w popisowych formach wypowiedzi typu występy na FameLab - wymaga odmiennej konfiguracji celów retorycznych. Czytelnicy gazet czy publiczność imprez popularnonaukowych poszukują przyjemnych doświadczeń związanych z odbiorem przekazywanych treści, a redaktorzy, dziennikarze, prezenterzy muszą dbać o przychylność swoich klientów. Stąd najistotniejszy cel retoryczny to delectare: komunikat ma się podobać, być łatwo przyswajalny i przyjemny w odbiorze. Estetyka przekazu ma wspomagać cel $d o-$ cere (w tym wypadku: informowanie o koncepcjach naukowych). Skoro, zgodnie z typologią Werlicha, chodzi o teksty „referujące”, a nie argumentacyjne, cel movere powinien dotyczyć tylko przedstawienia tego, jak naukowiec, środkami naukowymi, dowodził słuszności jakiejś koncepcji naukowej. Jednak nierzadko dziennikarze, dla zwiększenia zainteresowania odbiorców tematem - czyli zgodnie z własnymi celami - przekonują do tez znacznie silniejszych niż te przedstawione w oryginalnym tekście naukowym (na przykład, aby nadać informacji cechy sensacji).

Dla syntetycznego przedstawienia różnic między komunikacją naukową a popularną, inspirowanego powyżej zacytowanym tekstem, zostaną wykorzystane - w nietypowej kolejności - trzy kategorie retoryczne: dispositio, inventio i elocutio.

${ }^{12}$ Zob. T. Sierotowicz, Od metodycznej polemiki do polemiki metodologicznej. Impresje z lektury ,Wagi probierczej” Galileusza wraz z antologia, Wydawnictwo Diecezji Tarnowskiej Biblos, Tarnów 2008. 


\section{Dispositio}

Według antycznego modelu tworzenia tekstu dispositio stanowi drugi po inventio etap organizacji tekstu. W oryginalnym ujęciu retoryczna dispositio jest traktowana jako ogólny schemat tekstu argumentacyjnego (od exordium do peroratio), niezależnie od zróżnicowania na gatunki mowy.

We współczesnych badaniach, łączących retorykę z analizą dyskursu i analizą gatunków mowy, retoryczna dispositio jest omawiana również w odniesieniu do układów informacji, typowych dla poszczególnych gatunków mowy ${ }^{13}$. W takim podejściu dispositio jest ujmowana także jako swoisty środek inwencyjny: części funkcjonalne, wymienione w schemacie tekstu, skłaniają lub wręcz zmuszają autora do uwzględnienia właśnie tego typu informacji. W takich kategoriach można potraktować schemat artykułu naukowego (tj. research paper) w naukach ścisłych i przyrodniczych, tzw. IMRAD (Introduction-Methods - Results - And - Discussion ${ }^{14}$.

Cytowana we wstępie zoolożka, gdyby pisała artykuł naukowy, musiałaby podać w tej właśnie kolejności wymagane kategorie informacji. Pominięcie sekcji „Metoda” i „Rezultaty” oznaczałoby dyskwalifikację artykułu: metodologia, rygory przeprowadzenia doświadczenia lub obserwacji, skrupulatne wyliczenie uwzględnianych zmiennych oraz uzyskanych wyników stanowią bowiem fundament rzetelności naukowej. Sekcje te zawierają zatem informacje umożliwiające innym badaczom ocenę wiarygodności badania i jego interpretacji teoretycznej oraz ewentualną samodzielną weryfikację według zadeklarowanej metody. W związku z tym artykuły muszą być odpowiednio długie (minimum 12 stron), aby mogły pomieścić wszystkie niezbędne szczegóły.

W tekstach mówiących o nauce w sposób popularny liczy się przede wszystkim krótkość. Wspominany konkurs FameLab narzuca ograniczenia czasowe wypowiedzi do 3 minut (odpowiednik ok. 1,5 strony), zmuszając uczestników do wykorzystywania mechanizmów retorycznych przydatnych w reklamach czy trailerach filmów. Preferencja dla komunikacji brachylogicznej (z gr. brachylogia, dosł. 'krótkie słowo') oznacza także skróty i wybiórczość w stosunku do treści oryginału. Selekcjonując informacje, „oszczędza się” głównie na tym, co naukowcom umożliwia samodzielność i krytyczne podejście do przedstawianych koncepcji, a mianowicie na informacjach o założeniach teoretycznych, metodach,

${ }^{13}$ Zob. R.M. Coe, ,An arousing and fulfilment of desires”. The rhetoric of genre in the process era - and beyond, [in:] Genre and the new rhetoric, ed. A. Freedman, P. Medway, Taylor and Francis, London 1994, pp. 181-190; M. Załęska, Retorica della linguistica. Scienza, struttura, scrittura, Peter Lang, Frankfurt am Main etc. 2014.

${ }^{14}$ Zob. J.M. Swales, Genre Analysis. English in Academic and Research Settings, Cambridge University Press, Cambridge 1993. 
zmiennych. Z modelu IMRAD wybrane do popularyzacji kategorie informacji dotyczą głównie tego, co jest najbardziej widoczne i widowiskowe: sekcji „Wyniki” i „Dyskusja”. Oczywiście także te informacje są przekazywane w sposób selektywny, ograniczając się do najbardziej efektownych rezultatów i najciekawszych wniosków. Innymi słowy, w tekstach popularyzujących naukę nie ma ustalonych kategorii informacji (typu IMRAD), lecz obowiązuje najprostszy układ, który można zidentyfikować w każdym tekście: wstęp, rozwinięcie i zakończenie.

\section{Inventio}

Sama retoryka jest rozumiana przez Arystotelesa właśnie w kategoriach inwencyjnych, jako wspomniana wyżej umiejętność odkrywania w każdym przypadku tego, co przekonywające. Teksty naukowe i teksty popularyzujące naukę to inne przypadki - ze względu na inne cele poznawcze i odmienne audytoria.

W tekstach naukowych (,ezoterycznych”, według wspomnianej nomenklatury starożytnej) umiejętność odkrywania tego, co przekonywające dotyczy głównie przekonywania do meritum. Naukowcy jako profesjonaliści w danej dyscyplinie mają zawodową motywację do bycia na bieżąco z literaturą naukową. Badania innych bowiem mogą przybliżać ich do odpowiedzi na fundamentalne dla nauki pytanie: jak się rzeczy mają? W związku z tym tytuły artykułów naukowych nie muszą kusić estetyką czy emocjami (cel: delectare), lecz raczej rzeczowo informować o temacie tekstu (cel: docere). Zaciekawienie czytelnika-specjalisty odbywa się zazwyczaj poprzez odwołanie się, już w sformułowaniu przyczyny napisania tekstu (causa scribendi), do wartości istotnych w nauce jako bezinteresownym poznawaniu wiedzy dla wiedzy. Udzielone odpowiedzi na te pytania pozostają na poziomie abstrakcyjnym, bez wskazywania związku z życiem czytelników. Wpływa to na konstrukcję trzech elementów inwencji retorycznej: etosu, patosu i logosu.

W ujęciu Arystotelesa etos jako wiarygodność mówcy składa się z trzech elementów: phronesis, arethé i eunoia. Phronesis ('zdrowy rozsądek') to ten komponent etosu, dzięki któremu mówca jawi się jako osoba zdolna wskazać środki do osiągnięcia pożądanych przez słuchaczy i zgodnych z ich wartościami celów; dzięki arethé ('szlachetności') mówca podkreśla, że faktycznie podziela wartości audytorium; eunoia ('dobra wola') to dawanie do zrozumienia, że mówca działa na korzyść słuchaczy.

W tekstach naukowych phronesis przejawia się m.in. dzięki wskazywaniu środków - założeń teoretyczno-metodologicznych, szczegółowemu określeniu danych i sposobów ich opracowania - co pomoże innym naukowcom w osiągnięciu pożądanych w tym środowisku celów: ustalenia, jak się rzeczy mają. Przyczynia 
się to także do realizacji arethé, wskazując na podzielane przez autora wartości odbiorców jego tekstu, należące do kategorii wartości epistemicznych (prawda, jakość poznania, krytyczne myślenie, weryfikacja wiedzy). Dzięki temu można ocenić, że mówca działa na korzyść odbiorców-naukowców (eunoia).

Obok specyficznej konstrukcji etosu, drugi retoryczny element emocjonalny - patos - w nauce miałby działać, paradoksalnie, poprzez programową jego eliminację. Teksty naukowe są konstruowane są bowiem jako beznamiętne, przemawiające jedynie do rozumu, niepobudzające emocji ${ }^{15}$.

$\mathrm{Z}$ punktu widzenia logosu tradycyjne ujęcie nauki oddaje słynne zdanie Marii Curie-Skłodowskiej: „W nauce nie powinniśmy się interesować ludźmi, ale faktami". Argumentacje w tekstach naukowych programowo mają być „apersonalne": dotyczyć relacji między faktami, danymi, zmiennymi. Według swoistych „reżimów prawdy” w poszczególnych dyscyplinach „to, co może być przekonujące" dotyczy m.in. sprecyzowania założeń teoretyczno-metodologicznych, w ramach których uzyskane wyniki niosą jakąś informację (np., w powyżej cytowanym przykładzie, teorii relacji przyczynowo-skutkowych, która pozwala połączyć wydzielanie melatoniny z wzorcami behawioralnymi).

W komunikacji ,egzoterycznej” (wedle przywołanej powyżej nomenklatury) owa umiejętność odkrywania w każdym przypadku tego, co przekonywające, dotyczy po pierwsze samego skłonienia audytorium do zapoznania się z tekstem. Szeroko pojmowany „ogół” (choć ta kategoria faktycznie wymagałaby doprecyzowania, na które tu nie ma miejsca) - czytelnicy gazet, widzowie np. na konkursie FameLab - nie mają ani zawodowego zainteresowania, ani (jak zwykle uważają) własnego interesu w śledzeniu bieżącego rozwoju nauki. Stąd pierwszym zadaniem retorycznym autora jest w ogóle przyciągnięcie uwagi do tematyki naukowej. Dlatego właśnie tak ważna jest realizacja retorycznego celu delectare, począwszy od samego tytułu tekstu. Tytuły mają za zadanie przyciągnąć uwagę, a causa scribendi ma być podana w sposób atrakcyjny. Skoro etymologicznie atraho to 'przyciągam', co okazuje się przyciągające dla odbiorców-nienaukowców?

Teksty popularyzatorskie nie są skierowane do specjalistów w danej dziedzinie wiedzy, a zatem etos autora musi być konstruowany inaczej. W tekstach popularyzatorskich phronesis jest konstruowana poprzez ukazywanie wiedzy naukowej jako środka służącego osiągnięciu podzielanych przez ogół celów: własnego lepszego życia, zdrowia, bogactwa, sprawczości itd. Takie ujęcie tematu przyczynia się do realizacji arethé: autor pokazuje, że nawet jako naukowiec podziela wartości odbiorców swojego tekstu, takie jak wartości społeczne, hedonistyczne

${ }^{15} \mathrm{O}$ źródłach takiego ujęcia emocji w kontekście praktyk poznawczych zob. Ch. Plantin Les bonnes raisons des émotions. Principes et méthode pour l'étude du discours émotionné, Peter Lang, Bern etc. 2008. 
czy pragmatyczne (zwiększanie kontroli i sprawczości, aby móc skuteczniej realizować własne cele życiowe). Tego typu ujęcie problematyki wskazuje na dbałość autora o eunoię, trzeci element etosu: mówca może być postrzegany dzięki temu jako faktycznie działający dla dobra swojego audytorium.

Dla przyciągnięcia uwagi niespecjalistów potrzebne jest także umiejętne operowanie patosem: temat ma wzbudzać emocje także po to, aby zwiększyć poziom informatywności tekstu (rozumianej, za Robertem de Beaugrande i Wolfgangiem U. Dresslerem ${ }^{16}$, jako stopień, w jakim dana informacja jest nowa dla odbiorców). W podanym przykładzie odbiorcom w ogóle nie przyszłaby na myśl intrygująca relacja między snem a rozmiarem intymnych części ciała. Elektryzujące pytanie (,Spytałam panów, czy spaliby spokojnie, gdybym im powiedziała, że podczas snu kurczą im się jądra") przyczyniło się do usensacyjnienia przekazywanej wiedzy, wzbudzając lekki niepokój, a jednocześnie wesołość audytorium.

Z punktu widzenia logosu, jak widać w zacytowanym przykładzie, podstawową decyzją retoryczną autorki zwycięskiej prezentacji było przyciągnięcie uwagi do kwestii zoologicznych poprzez ,przetłumaczenie” ich na kategorie antropologiczne, innymi słowy - pokazanie odbiorcom, jak przedstawiana sprawa dotyczy bezpośrednio ich doświadczeń. Ujęcie nauki w sposób antropocentryczny sprawia, że w tekstach popularyzatorskich argumentacja ma dotyczyć „prawdy przydatnej” dla człowieka. Argumenty zatem nie dotyczą tylko relacji między „rzeczami” (np. przyczyna - skutek), lecz także podtrzymywania zainteresowania poprzez wskazywanie bezpośredniego ,interesu” słuchaczy („Czy to mi pomoże w moim życiu"?) w zapoznaniu się z tematem.

\section{Elocutio}

W powszechnym odczuciu najbardziej podstawowa - bo najbardziej dostrzegalna - różnica między tekstami naukowymi a popularyzatorskimi dotyczy elocutio. Wiedza naukowa oznacza bowiem m.in. także opanowanie bardzo zaawansowanych kompetencji lingwistycznych i dyskursywnych, swoistych ,języków obcych", wyrażających formy poznania kontrintuicyjnego w rozmaitych dyscyplinach. Słownictwo stanowi świadectwo działalności kognitywnej człowieka. Czasem zachowuje ono ślady teorii z różnych etapów rozwoju nauki (np. zwrot Stońce wschodzi i zachodzi to nawiązanie do ówczesnych koncepcji astronomicznych). Posługiwanie się przez naukowców terminologią danej dyscypliny naukowej jest dla nich ekonomiczne i wygodne, gdyż opanowali cały system odniesień

${ }^{16}$ R.-A.de Beaugrande, W.U. Dressler, Wstęp do lingwistyki tekstu, przeł. A. Szwedek, PWN, Warszawa 1990. 
semantycznych obowiązujących w danej dyscyplinie i rozumieją tzw. metafory konstytutywne w swoich dyscyplinach (tj. metafory, stanowiące sposób ujęcia tematyki, np. język ujęty w metaforę struktury, rodziny czy warstw geologicznych).

Dla niespecjalistów odbiór owego ,języka obcego" wymaga ogromnego wysiłku intelektualnego, często przewyższającego ich możliwości. W zacytowanej powyżej rozmowie od naukowców popularyzujących naukę oczekuje się przestrzegania wymogu zrozumiałości dla laików. Należy zatem przetłumaczyć z „obcego” (choć polskiego) na „,nasze” poprzez sprowadzenie poznania kontrintuicyjnego i poznania intuicyjnie oczywistego, codziennego, do wspólnego mianownika językowego i pojęciowego. Dzięki odwołaniom do tego, co wspólne - do słów, metafor czy porównań do doświadczenia codziennego - laicy, w toku krótkiej prezentacji czy lektury krótkiego tekstu w mediach, mogą uzyskać pewne przybliżone pojęcie o omawianym zagadnieniu naukowym. Jest to raczej obznajomienie z tematem (ang. familiarity) niż rzetelna wiedza (ang. knowledge). Chwytliwe porównania, anegdoty itp. realizacje retorycznego celu delectare łatwo zapadają odbiorcom w pamięć. W związku z tym łatwo im przekazywać dalej tak przedstawione informacje. Realizacja celu delectare przyczynia się zatem do uzyskania przez treść tak pożądanej w popularyzacji wiedzy cechy bycia wdzięcznym tematem rozmów (ang. tellability).

\section{Podsumowanie}

A zatem, czy mówiąc inaczej (albo naukowo, albo popularyzatorsko) - mimo wszystko mówimy to samo? Z przeprowadzonej analizy wynika, że pozostaje rozpoznawalny temat (,opowiadałam [...] o chomikach, którym podawano melatoninę"), ale wybory retoryczne - na poziomie gatunków mowy wraz z ich specyficzną dispositio, na poziomie inventio i elocutio - mają daleko idące konsekwencje. Każdy zysk (krótkość, atrakcyjność, prostota, zrozumiałość dla niespecjalisty) ma swoją cenę: w tekstach popularyzujących wiedzę mówi się nie tylko innymi słowami, nie tylko krócej, ale też trochę inne rzeczy, przechodząc z abstrakcji do konkretu bezpośredniego doświadczenia w życiu słuchaczy; z kwestii dotyczących „rzeczy” do ujęcia antropocentrycznego, dotyczącego ludzi; z kwestii „bezinteresownego zainteresowania” nauki tym, jak się rzeczy mają niezależnie od spodziewanych korzyści dla człowieka, do „zainteresowania interesownego”, czyli wykazywania praktycznych korzyści dzięki zapoznaniu się z przedstawianymi treściami. Trawestując zatem słowa Stanisława J. Leca, przywołane jako motto tego tekstu, okazuje się, że w popularyzacji naukowej nie wystarczy mówić o rzeczach. Trzeba mówić o ludziach. 


\section{Bibliografia}

Beaugrande R.-A.de, Dressler W.U., Wstęp do lingwistyki tekstu, przeł. A. Szwedek, PWN, Warszawa 1990.

Coe R.M., ,An arousing and fulfilment of desires”. The rhetoric of genre in the process era-and beyond, [in:] Genre and the new rhetoric, ed. A. Freedman, P. Medway, Taylor and Francis, London 1994, pp. 181-190.

Donghi P., Sui generis. Temi e riflessioni sulla comunicazione della scienza, Gius, Laterza \& Figli, Roma-Bari 2006.

Gotti M., Specialized discourse: linguistic features and changing conventions, Peter Lang, Bern 2003.

Konik T., Przypadki retorycznie istotnych zmian redakcyjnych $w$ tlumaczeniach publicystyki prasowej o tematyce gospodarczej, [w:] Retoryka w komunikacji specjalistycznej, red. M. Załęska, Polskie Towarzystwo Retoryczne, Warszawa 2015, s. 187-216.

Myers G., Discourse studies of scientific popularization: questioning the boundaries, "Discourse Studies" 2003, 5 (2), pp. 265-279.

Piekot T., Mechanizmy popularyzowania wiedzy naukowej, [w:] O trudnym łatwo: materiaty sesji poświęconej popularyzacji nauki, red. J. Miodek, M. Zaśko-Zielińska, Wydawnictwo UWr, Wrocław 2002, s. 95-110.

Plantin Ch., Les bonnes raisons des émotions. Principes et méthode pour l'étude du discours émotionné, Peter Lang, Bern etc. 2008.

Shapin S., Never Pure. Historical Studies of Science as if It Was Produced by People with Bodies, Situated in Time, Space, Culture, and Society, and Struggling for Credibility and Authority, The Johns Hopkins University Press, Baltimore 2010.

Sierotowicz T., Od metodycznej polemiki do polemiki metodologicznej. Impresje z lektury „Wagi probierczej" Galileusza wraz z antologia, Wydawnictwo Diecezji Tarnowskiej Biblos, Tarnów 2008.

Starzec A., Przemiany w popularyzacji prasowej, [w:] O trudnym łatwo: materiaty sesji poświęconej popularyzacji nauki, red. J. Miodek, M. Zaśko-Zielińska, Wydawnictwo UWr, Wrocław 2002, s. 24-31.

Swales J.M., Genre Analysis. English in Academic and Research Settings, Cambridge University Press, Cambridge 1993.

Toulmin S., Rieke R.D., Janik A., An Introduction to Reasoning, Macmillan Publishing Company, New York-London 1984.

Werlich E., Typologie der Texte. Entwurf eines textlinguistischen Modells zur Grundlegung einer Textgrammatik, Quelle \& Meyer, Heidelberg 1975.

Załęska M., La semplicità e la semplificazione: fra l'ideologia e la retorica, "Circula: Révue d'idéologies linguistiques" 2015, No 2, pp. 192-211, http://circula.recherche.usherbrooke. ca/2015-numero-2-fr/ [dostęp: 3.11.2015].

Załęska M., Retorica della linguistica. Scienza, struttura, scrittura, Peter Lang, Frankfurt am Main etc. 2014.

Załęska M., Retoryka a wiedza: komunikacja niespecjalistyczna i specjalistyczna, [w:] Retoryka w komunikacji specjalistycznej, red. M. Załęska, Polskie Towarzystwo Retoryczne, Warszawa 2015, s. 53-83.

Zoolożka, z J. Bagniewską rozm. M. Borowska, „Gazeta Wyborcza” 2014, 28.06, dodatek „Wysokie Obcasy", nr 25 (784), s. 8-13. 
Maria Załęska

\title{
Rhetorical Aspects of Popular Science
}

\begin{abstract}
(Summary)
After having distinguished the two main contexts for the transmission of knowledge - the esoteric and exoteric - the paper offers a systematic comparison between scientific and popular science texts in terms of inventio, dispositio and elocutio. The popular science texts tend to present knowledge in anthropocentric terms, showing the relevance of the message to the recipients' everyday lives. They turn out to be shorter than genuine scientific texts, and this is achieved, among others, by eliminating information about the methodologies used. The user-friendly vocabulary offers the audience a sense of familiarity with the presented topic, which is, however, different from in-depth specialist knowledge.
\end{abstract}

Key words: scientific popularization, rhetoric, inventio, dispositio, elocutio. 